\title{
The Improvement Of Reading Comprehension Through Student Team Achievement Division (STAD)
}

\author{
$\operatorname{Desy}_{\text {Chaniago }}{ }^{1} *$, Depi Yunaspi ${ }^{2)}$ \\ 1,2) Program Studi Sarjana Gizi, Institut Kesehatan Mitra Bunda \\ *Corresponding author \\ Email:dhephoy02@gmail.com
}

\begin{abstract}
The purpose of research is to improve the skills learners in understanding the reading text in English through STAD cooperative learning methods. The subjects were students VIII.F class in SMPN 92 Jakarta. Data collected at the initial observation as the first data, and then drafted two cycles are expected to be able to improve the skills of learners in understanding reading English text. The research model using action research model of Kurt Lewin, namely planning, action, observation and reflection. This action research was conducted over a six-month consisting of two observation meetings and eight meetings in two cycles. Four meetings, the first cycle and the second cycle of four meetings. Repairs carried out in every cycle and follow the post-test at the end of learning. Data were analyzed through qualitative and quantitative procedures. The study states that the ability of learners to understand the English text on the first cycle only 77.06. Then, the ability of learners rose to 82.55 in the second cycle. Based on that, the cooperative learning model of STAD very effective in improving the quality of the learning process and the ability of learners in understanding English texts
\end{abstract}

Keywords: Cooperative Learning, readIng Comprehension, STAD

\section{INTRODUCTION}

Reading is one of the important things for human life. Reading is important because in various activities carried out by humans, it is needed to support each of these activities. The ability to read someone can be obtained or trained through the world of education. Reading is one of the important skills for learners to expand their knowledge of the language, cultures, and the world. Learners can get more information that they need through reading different materials, such as magazines, newspapers, novels, books, journals, and so on.(Prof. Dr. I Made Yudana \& Prof. Dr. I Nyoman Natajaya, 2013)

Reading is a process that is carried out and used by the reader to obtain a message, which the writer wishes to convey through the medium of words or written language. A process that requires that groups of words which are a unit will be seen in a glance and the meaning of words individually can be known. If this is not fulfilled, the written and implied message will not be captured or understood, and the reading process will not be carried out properly (Hodgson in Tarigan, 2008: 7). Reading is one of the four basic language skills or language skills. The basic language skills or language skills in the curriculum in the school include four aspects, namely: (a) listening skills (listening skills), (b) speaking skills, (c) reading skills (reading skills), and (d) writing skills (writing skills) (Tarigan, 2008: 1).

Understanding is the most important stage in reading, according to the Oxford dictionary understanding or comprehension is a form of ability to understand especially in speaking and understanding, besides comprehension is an exercise to train students in 
understanding language (Dictionary Oxford, 2000: 263). Anderson in Klinger explained that reading comprehension is a very complicated process consisting of word reading, word knowledge, and reading fluency (Klinger, 2007: 2). Someone can be said to understand the reading if the three processes are fulfilled, starting from understanding each word contained in the reading then the knowledge of the word and fluently in reading the reading. In addition to these three processes, understanding reading certainly requires deep understanding, especially for knowing the main ideas of reading and specifically can know the specific information contained in the reading.

One learning model that can be used by teachers to involve the liveliness of the students is the learning model Type Student Team Achievement Division (STAD). Learning with the STAD type cooperative learning emphasizes collaboration in teach groups that require students to help each other, motivate and trust each other so that they are able to create active, innovative, creative and fun learning for students during the learning process. Such learning will be able to arouse enthusiasm for students to learn so that it will affect the achievement of optimal student learning outcomes.

\section{RESEARCH METHODS}

\section{Student Team Achievement Division (STAD) Learning Method}

English learners at junior high school in Jakarta consist of diverse characters of students where the level of ability and understanding of the language is very diverse so the instructor must find the right learning method so that the teaching and learning process can run well and the results are as expected. One method used is the STAD type cooperative learning method which is assumed to be in accordance with the conditions of students who are heterogeneous in English learning.

The STAD cooperative learning method can be described as a learning model that emphasizes attitudes or shared behaviors in working or helping among others in the structure of regular cooperation in groups. The cooperative learning method type STAD has a basis in cognitive psychology theory and social learning theory.

STAD type cooperative learning method is seen as the simplest, and most widely used and most directly from the cooperative learning approach. Slavin explained that STAD is one of the simplest cooperative learning methods, and is the best model for beginning for new teachers using a cooperative approach (Slavin, 2013: 143)

In this study, the criteria developed by Lin and Gronlund were used because this version of the assessment format was most suitable for reading comprehension. The assessment of reading comprehension ability in the Lin and Gronlund format focuses on the following aspects: 1) Identifying the meaning of words given, 2) Identifying the meaning of words when used in context, 3) Identifying the words conveyed in the text in detail, 4) Identifying the points thoughts conveyed indirectly in a text, 5) Identifying causal relationships in a text, 6) Identifying the main thoughts or goals in a text, 7) Identifying the ability to draw conclusions from a text (Lin and Gronlund, 1995: 379 )

Slavin stated that learning using Cooperative Learning models generally has the following characteristics: 1) Group goals, 2) Individual responsibility is carried out in two ways, namely the average individual and task specialization, 3) The same chance of success in each group learning, 4) Team competition is as a means to motivate students to work with group members, 5) Specialization of tasks is the task of carrying out sub-tasks towards each group member, 6) Adaptation to group needs (Slavin, 2013: 26- 28). STAD type cooperative learning method that 
applies five main components / steps, namely: class presentations, teams, quizzes, individual progress scores and team recognition (Slavin, 2013: 143-144).

\section{RESULTS AND DISCUSSION}

This type of research is action research that aims to find out and describe the learning process of increasing the ability to understand the English text of students through the STAD type cooperative learning approach and to determine the extent of the effectiveness of the STAD type learning method in improving reading comprehension and to know the extent understanding reading can be improved through the STAD type cooperative learning approach to class VIII English learners at junior high school in Jakarta. The action research model used was the model of Kurt Lewin. This stage of action research includes four stages, namely the stages of planning, action, observation and reflection.

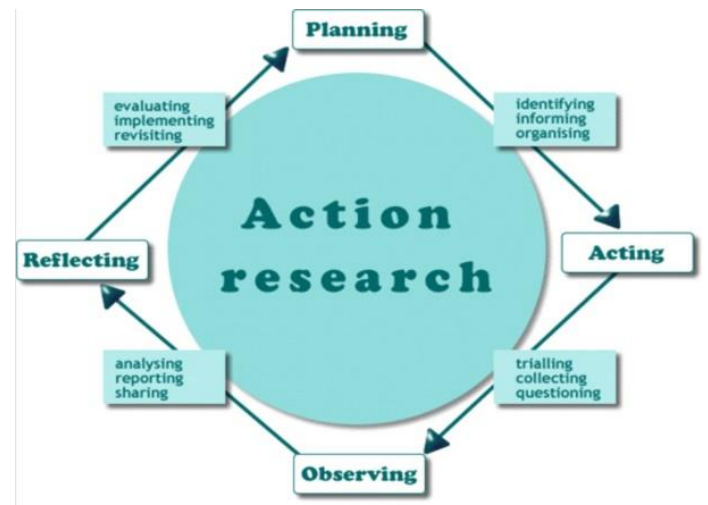

Figure 1. Kurt Lewin Research Model

The number of eighth grade students, especially VIII.F is 36 people consisting of 12 male students and 24 female students. English subjects are held every Monday at 11:00 to 13:00 and Wednesday 9:40 to 11:00. To find out the factual state of English students' reading comprehension abilities, researchers first conducted observations and interviews with students. Based on observations made by researchers in preliminary observations and interviews, researchers concluded that the obstacles experienced by students mostly included internal and external factors related to reading comprehension abilities, namely: (1) accuracy in interpreting the meaning of words or phrases, (2) understanding the structure generic of each type of text studied, (3) understanding the meaning implied in the reading text or in the form of questions, (4) the ability to understand the contents of the reading in general or paragraph.

Before the first cycle, the teacher conducts the initial test. The purpose of the initial test in this research is to explore the extent to which students are able to understand English texts. After the initial test, the average score obtained by students is still low at 65.06. According to the results of the initial test it is known that the lowest score is 46 ( 1 person) and the highest score is 80 (1 person). The value of the initial test is still far from the standard set value of 80 . Based on the results of the scores from the initial tests obtained by students it can be concluded that the ability to understand the English text of students is still low. The researcher gave action by teaching English lessons using the STAD type cooperative learning method in the first meeting - three cycles I using lecture techniques, question and answer, group discussions, group work and assignments. By using this technique it is expected that students can understand the subject matter at that time. At the end of the first cycle, researchers gave a test of the ability to understand English reading using the STAD type cooperative learning method and it was known that in general the teaching using the STAD cooperative learning method 
was able to improve students' reading comprehension ability, but still the majority of students were not maximal in expressing opinions about the text and also understanding the author's purpose in the text. This can be seen from the results of the average value contained in the aspect of understanding evaluation obtained by students is 70.22 .

The ability to understand English reading in grade VIII.F English learners at junior high school in Jakarta increased after the action was carried out in the first cycle. This can be seen from the average value of the initial test of 65.06 which increased to 75.88 in the first cycle test. Initially only $2.78 \%$ or one student completed with a score of 80 but on the first cycle test increased to $63.88 \%$. Most of them have achieved completeness scores, which mean that the resulting scores are already above 80 . Of the 36 students there are 14 that meet the school KKM value standards. And 22 students are still under the KKM. After the first cycle post-test results are analyzed in depth, students experience the greatest difficulty when answering the implicit questions or at the interpretative level and application and lack of vocabulary mastery.

In the second cycle, the students' reading comprehension ability increased even more. This can be seen from the increase in learning scores from the results of the average value starting from the pre-test which the average student still got a score of 65.06, increasing at the end of the first cycle to 75.88 and at the end of the second cycle increasing again to 82, 55 . Initially only $38.89 \%$ or 14 students who completed the first cycle test increased to $69.44 \%$ or 27 students who completed the second cycle. Most of them have achieved completeness scores, which means that the scores produced are many that are above 80 . Of the 36 students there are 23 who meet the school KKM value standards. And 13 students are still under the KKM.

The increase that occurred in this cycle was due to the emphasis and delivery of messages by the instructor about the importance of the material to be discussed by the students, the change in the way the discussion was conducted by students so that the ability to understand the text was previously only dominated by some of them who were smart II this ability is evenly distributed to the other members of the students, and begins to be unfamiliar with students with English language vocabulary related to the material presented, so in the second cycle students begin to understand the vocabulary more quickly and be able to find new vocabulary that has not they understand. Based on the acquisition of the values obtained in the second cycle, it can be concluded that the research has reached the indicator of success of the research, there are more than $80 \%$ of students who reach values above 80 , and from these conclusions it is stated that this study has achieved completeness and is not needed further research

\section{CONCLUSION}

Based on the results of the research that has been done, conclusions can be drawn based on the research questions, as follows:

First, the process of improving the ability to understand English reading using the STAD type cooperative learning method applied in the learning process both cycle I and cycle II runs smoothly in class VIII.F English learners at junior high school in Jakarta.

Second, the results of the application of the STAD type cooperative learning method to class VIII students, especially VIII.F showed that the STAD type cooperative learning method was very effective to use in learning English to improve learning outcomes of students.

Third, English reading comprehension skills can be improved through the Student Team Achievement Division (STAD) for Class VIII English learners at junior high school in Jakarta. This is evidenced by the achievement of the indicators of the success of reading of students in 
the second cycle, the achievement of the average value of students in the early stages of observation was 65.06 and there was an increase of 10.82 points at the end of the first cycle of 75.88 and at the end of the second cycle there was an increase of 6.37 points which was equal to 82.25 at the end of the second cycle. At the end of the first cycle there was an increase in completeness of students by $36.11 \%$ in the first cycle from $2.77 \%$ to $38.88 \%$ and in the second cycle there was an increase of $44.45 \%$ from $38.88 \%$ to $83.33 \%$. However, from the results obtained by the students in the pre-test, cycle I and cycle II, the STAD type cooperative learning method was appropriate and effective in increasing students' English reading comprehension.

\section{REFERENCES}

Hornby, A.S. 2000. Oxford Advanced Learner's Dictionary of Current English 6th Edition. New York: Oxford University Press.

Klinger, Jannette and Vaughn, Sharon. 2010. Using Collaborative Stategic Reading. (Collorado: University of Collorado at Boulder.

Linn, Robert L and Grounlund, Norman E. 1995. Measurement and Assessment in Teaching. New York: Jersey Prentice Hall.

Rahmi, Farida. 2007. Pengejaran Membaca di Sekolah Dasar. Jakarta: PT. Bumi Aksara.

Slavin, Robert E. 2013. Cooperative Learning Teori, Riset dan Praktik. Bandung: Penerbit Nusa Media.

Tarigan, Henry Gutur. 2008. Membaca Sebagai Suatu Keterampilan Berbahasa. Bandung: Angkasa 